\title{
Influence of Plant Extracts and Essential Oils against Panama Disease (Fusarium oxysporum f. sp. cubense) in Banana Seedlings
}

\author{
Fernando P. Monteiro ${ }^{1}$, Larissa C. Ferreira ${ }^{1}$, Jhonata L. Silva ${ }^{1}$, Leandro P. Pacheco ${ }^{2} \&$ Paulo E. Souza $^{1}$ \\ ${ }^{1}$ Department of Plant Pathology, Federal University of Lavras, Lavras, Brazil \\ ${ }^{2}$ Department of Plant Science, Federal University of Piauí, Bom Jesus, Brazil \\ Correspondence: Fernando P. Monteiro, Department of Plant Pathology, Federal University of Lavras, Lavras, \\ Brazil. Tel: 55-35-9169-5159. E-mail: fernandopereiram@bol.com.br
}

Received: December 19, 2012 Accepted: January 30, 2013 Online Published: March 15, 2013

doi:10.5539/jas.v5n4p63

URL: http://dx.doi.org/10.5539/jas.v5n4p63

\begin{abstract}
The current research aimed to study the efficacy of plant extracts and essential oils from Rosmarinus officinalis, Thymus vulgaris, Cinnamomum zeylanicum and Syzigium aromaticum on mycelial growth and conidial germination of Fusarium oxysporum $\mathrm{f}$. sp. cubense in vitro, as well as evaluation in vivo. Essential oils and extracts were applied in the culture medium (PDA) at melting point to estimate the direct effect on mycelial growth. Also, the estimation of volatile substances against mycelial growth was done. The obtained results indicated that plant extracts and essential oils of Cinnamomum zeylanicum and Syzigium aromaticum were effective at $500 \mathrm{ppm}$ with direct effect against mycelial growth. The volatile plant extracts had no effect on mycelial growth, however, the volatile essential oils of Cinnamomum zeylanicum and Syzigium aromaticum showed good effects in controlling the disease in both 1000 and 2000 ppm. Meanwhile, extracts and essential oils of Cinnamomum zeylanicum and Syzigium aromaticum showed efficacy on the conidial germination. In vivo, both essential oils and extracts from Cinnamomum zeylanicum and Syzigium aromaticum, in addition to fungicide (Trifloxystrobin + Tebuconazole) which was effective in avoiding the spread of disease.
\end{abstract}

Keywords: Rosmarinus officinalis, Thymus vulgaris, Cinnamomum zeylanicum, Syzigium aromaticum

\section{Introduction}

The banana is an important fruit for Brazilian economy and likewise is highlighted as a second largest exporter of bananas. The production in 2011 was about 7.023 million tons of fruit and the harvest planned for 2012 is about 6.980 million tons. The Banana cultivation in 2011 earned revenues about of U\$ 40 million in exports of fresh fruit with an export volume about of 110.053 tons. The planted area was 510.654 ha with an average yield of 14.385 $\mathrm{kg} / \mathrm{ha}$. The major producing fields are those located in the Northeast, Southeast and, to a lesser extent the South. The Brazilian cities that had the produce highlighted were São Paulo and Bahia. (BRAZILIAN FRUIT YEARBOOK, 2012). Considering the world context, Brazil is located in fourth position as the largest banana producer, behind India, China and Philippines (Braga Filho et al., 2011). Among the most destructive diseases of banana, the Panama disease is considered the most important, reducing the production to values near to zero in some cases, where cultivars are susceptible.

The wilt disease of banana was first reported in Australia in 1876 by Bancroft, also being described by Higgins in 1904 in Honolulu, Hawaii, both descriptions were taken as the first reports. During the decades of 1950 and 1960 the Panama disease decimated banana plantations in Central America and the Caribbean (Daly \& Walduck, 2006; Ploetz \& Pegg, 1997). According to Gasparoto and Pereira (2006), Panama disease is a vascular disease whose etiological agent is Fusarium oxysporum f. sp. cubense. According to these authors the banana wilt disease was described in Brazil at 1930 on Piracicaba (São Paulo state) and today can be found in all banana-producing regions.

Considering the species of Fusarium oxysporum there are over 100 formae speciales, which causes the wilt in plants (Domsch et al., 1980; Nelson et al., 1983). According Ploetz et al. (2000) among these variations of species there are pathogenic and non-pathogenic isolates that cannot be distinguished morphologically. For the specific case of Fusarium oxysporum f. sp. cubense there are reports for four different races, but only three of them are pathogenic to banana especially for a kind of variety known as apple and silver sub group, the another race only attack the heliconia plant species (Stover, 1962; Ploetz \& Pegg, 1997). The pathogen can be dispersed through the 
soil, running water or agricultural machinery and implements, but mainly by contaminated rhizomes, used as seedlings in banana cultivation (Stover, 1962).

The disease induces premature death in adult plants near or during the flowering. Considering a susceptible banana variety and an extreme scenario, the losses can reach at $100 \%$ of the production (Pereira et al., 2005). Early symptoms are seen inside of the feeder roots, the place where occurs the initial infections (Beckman, 1990). According to Ploetz (2000) the symptoms can progress to the rhizome and cortex. The pseudo-stems are also colonized and faint brown streaks are evident, as well as inside the sheath of older leaves. Large portions of the xylem become brown with the disease progress. The external symptoms begin with yellowing of older leaves, followed by wilt of leaves and deformations starting on the petiole base.

Attempts to find new methods for efficient control have been held every day. Barbieri et al. (2006) tested new substances in the control of $F$. oxysporum $\mathrm{f}$. sp. cubense mycelia as stannous chloride dihydrate, triphenyltin acetate, mandelic acid, among others, which had different effects on disease control. The use of plant extracts and essential oils as an alternative treatment has also been discussed as a promising practice in controlling diseases. As the work of Cakir et al. (2005), who reported the fungicidal effect of the essential oil from Hypericum linarioides Bosse in six species of the genus Fusarium, among them, F. oxysporum. Bajpai et al. (2007) found the antifungal effect of the essential oil from Metasequoia glyptostroboides Miki ex Hu, at 1000 $\mu \mathrm{L}^{-1}$ showing inhibition on mycelial growth of Fusarium oxysporum at $63 \%$. Guimarães et al. (2011) showed inhibition of $F$. oxysporum f. sp. cubense when working with essential oil from Cymbopogon citratus and citral. Oliveira et al. (2008) found that $L$. sidoides was effective in inhibiting the mycelial growth of $F$. oxysporum f. sp. cubense with similar results imposed by carbendazin, which demonstrates the possibility for using these compounds without losses in efficiency compared to current products. Cruz et al. (2011) observed that although the oil Azadirachta indica had no effect on mycelial growth of $F$. oxysporum f. sp. lycoperseci, this decreased the disease severity in tomato, through the resistance induction. Based on these papers we can see the potential of essential oils and plant extracts in controlling of the diseases, incited by Fusarium species.

The objective of this study was to investigate the potential of essential oils and plant extracts of Cinnamomum zeylanicum Blume, Cymbopogon nardus (L.), Rosmarinus officinalis L. and Syzygium aromaticum (L.) Merr. and Perry in different concentrations, studying the effects on mycelial growth, spore germination and Panama disease severity on banana seedlings.

\section{Material and Methods}

\section{1 Extraction of Essential Oils and Plant Extracts}

Plant species were selected for the experiments according to the botanical family to which they belong: family Lamiaceae-Rosemary (Rosmarinus officinalis L.), Family Myrtaceae - Cinnamon (Cinnamomum zeilanicum Breym.), Clove (Syzigium aromaticum (L.) Merr \& Perry) and Family Poaceae - Citronella (Cymbopogon nardus (L.) Rendle).

The work was conducted in the laboratory and greenhouse in Federal University of Lavras. The plant extracts were obtained from vegetative or reproductive parts of the selected plants for the experiments that were collected in the Garden of Medicinal Plants at university. After collection the plants, these was washed with tap water and disinfected with sodium hypochlorite at $0.5 \%$ for 30 minutes to remove microorganisms present on the surface. Posteriorly, we performed triple rinsing under sterile distilled water to remove the remaining sodium hypochlorite. The material was dried on paper towels to remove excess moisture. Then, the material was packed in paper bags and placed in oven with air circulation at $45^{\circ} \mathrm{C}$ for 96 hours.

Subsequently, with the aid of slicer proceeded to grinding of those materials. Thus prepared, the powder was employed to obtain the aqueous extract by adding $10 \mathrm{~g}$ of the material in $100 \mathrm{~mL}$ of sterile boiling distilled water, yielding a crude extract in $10 \%$ which remained in the infusion at room temperature and no light for $24 \mathrm{~h}$. After this period it was filtered in the sterile gauze and Whatman filter paper $\mathrm{n}^{\circ} .1$ to obtain crude aqueous extract.

The Syzigium aromaticum extract was obtained collecting $10 \mathrm{~g}$ of the plant material, crushed into blender with $100 \mathrm{~mL}$ of sterile distilled water and it was prepared according to the methodology described above for the other extracts.

\subsection{Obtaining and Inoculum Production of Fusarium oxysporum $f$. sp. cubense}

The fungus was isolated from a rhizome of banana that was infected showing the disease symptoms. The rhizome was cut into small pieces and treated with ethanol $70 \%$ for one minute and sodium hypochlorite at $2 \%$ for three minutes. The laminar flow was used to place the rhizome fragments in equidistantly way in the culture medium Potato-Dextrose-Agar (PDA). 
The inoculum production was performed inserting little disks of culture medium with fungus in the center of Petri dishes with PDA. It was packed in suitable conditions $\left(20^{\circ} \mathrm{C}\right.$ and $12 \mathrm{~h}$ of light) until the fungus fill all the plate. After sporulation, conidia were collected adding $10 \mathrm{~mL}$ of sterile distilled water, rubbing a brush lightly over the colonies and subjecting the suspension to constant agitation for the spores liberation. It was determined the concentration of conidial suspension in Neubauer chamber, adjusting it to be used for inoculation $\left(1.3 \times 10^{7}\right.$ conidia. $\mathrm{mL}^{-1}$ of macroconidia and microconidia).

\subsection{Effect of Essential Oils and Plant Extracts on the Mycelia Growth}

The assay of mycelial growth was performed using inverted discs measuring $8 \mathrm{~mm}$ in diameter with mycelia and spores of the fungus deposited in the center of the Petri dish measuring $90 \mathrm{~mm}$ in diameter, containing PDA medium. The treatments were the plant extracts at concentrations of $1 \%, 5 \%, 10 \%$, and $20 \%$ and essential oils in concentrations of 250, 500, 1000 and $2000 \mathrm{ppm}$.

The negative control was Petri dishes with only PDA. The positive control was the chemical fungicide Trifloxystrobin + Tebuconazole. The plates were carefully sealed, identified and incubated in a growth chamber under a photoperiod of $12 \mathrm{~h}$ light and $12 \mathrm{~h}$ dark at $25^{\circ} \mathrm{C}$. The evaluations were performed by daily measurements of the colonies diameter (average of two measurements diametrically opposite), $24 \mathrm{~h}$ after starting the experiment and continued until the fungus fill the entire surface of the culture medium in one of treatments.

The experimental design was completely randomized. The data were subjected to analysis of variance performed by Sisvar program (FERREIRA, 2000) and means were compared by the Scott-Knott test at $5 \%$ probability. Regression analysis was presented only for effective treatments.

\subsection{Effect of Volatile from Essential Oils and Plant Extracts on the Mycelial Growth}

The assay with essential oils and plant extracts volatile were performed with disk diffusion test which consisted in the application of $30 \mu \mathrm{L}$ of antimicrobial agent suspension at different concentrations in filter paper fixed in one surface the Petri dish. On the opposite surface was deposited in the center of the plate, inverted discs with mycelia and spores, measuring $8 \mathrm{~mm}$ in diameter. The treatments consisted in herbal extracts at concentrations of $1,5,10$ and $20 \%$ and essential oils at concentrations of $250,500,1000$, and $2000 \mathrm{ppm}$, the negative control was the fungicide and the positive control was sterile distilled water. The plates were carefully sealed, identified and incubated in a growth chamber under a photoperiod of $12 \mathrm{~h} \mathrm{light}$ and $12 \mathrm{~h}$ dark at $25^{\circ} \mathrm{C}$. The evaluations were performed by daily measurements of the colonies diameter (average of two measurements diametrically opposite), starting at $24 \mathrm{~h}$ after the experiment and continued until the time when the fungus fill the entire surface of the culture medium in one of treatments.

The experimental design was completely randomized. Data were subjected to analysis of variance with Sisvar program (FERREIRA, 2000) and means were compared by the Scott-Knott test at 5\% probability. Regression analysis was presented only for effective treatments.

\subsection{Effect of Essential Oils and Plant Extracts on the Conidial Germination}

A trial to evaluate the germination of the pathogen was installed. We used Petri dishes measuring $6 \mathrm{~cm}$ diameter containing water-agar (WA) at $2 \%$. Inside these plates was added $1 \mathrm{~mL}$ of treatments at predetermined concentrations and also $1 \mathrm{~mL}$ of conidial suspension with a concentration adjusted to $1.5 \times 10^{5}$ conidia/mL using hemacytometer. Then, the plates were placed in a growth chamber at $25^{\circ} \mathrm{C}$ and $12 \mathrm{~h}$ of light for $24 \mathrm{~h}$. The experiment was conducted in a completely randomized design with two plates for each treatment, each one divided into four quadrants. It were evaluated 50 conidia per quadrant for a total of 8 repetitions. After incubation, the germination was stopped by the addition of two lactoglycerol drops. It was considered germinated, those conidia which showed germ tube. The positive control was sterile water and negative control was the fungicide $(1 \mathrm{~mL})$ in the same previous dose.

The experimental design was completely randomized. Data were subjected to variance analysis with Sisvar program (FERREIRA, 2000) and means were compared by the Scott-Knott test at 5\% probability. Regression analysis was presented only for effective treatments.

\subsection{Effects of Essential Oils and Plant Extracts in the Control of the Panama Disease in Banana Seedlings}

The inoculation in plant was done with $1 \mathrm{~mL}$ of a spore suspension, which was injected at $5 \mathrm{~cm}$ above the plants rhizomes with the aid of a hypodermic syringe. After inoculation, the plants received $100 \mathrm{~mL}$ of essential oils at a concentration of $1 \mathrm{ppm}$ and plant extracts at $10 \%$. For this procedure, the plants were irrigated with the treatments by adding $70 \mathrm{~mL}$ on the base of the plants and $30 \mathrm{~mL}$ was sprayed until the runoff point. The negative control was sterile water and as a positive control we used the Trifloxystrobin + Tebuconazole. 
After 23 days, we performed the evaluating the effect of alternative treatments to control the Panama disease. We respect the incubation period of the disease and onset of symptoms (23 days). The plants were evaluated considering the disease severity based on discoloration of rhizomes comparing the symptoms with the scale proposed by Mahomed et al. (1990).

The statistical design was a randomized complete block with 10 treatments (four essential oils, four plant extracts, one positive control with fungicide and one negative control with sterile distilled water), having three replications and three plants per plot.

The disease severity data were subjected to analysis of variance by $\mathrm{F}$ test, and when significant, the treatment means were compared by Scott-Knot at 5\% of probability in the statistical program SISVAR (Ferreira, 2000).

\section{Results and Discussion}

\subsection{Mycelial Growth under Influence of Essential Oils Incorporated into the Culture Medium}

The results for each treatment on mycelial growth showed significant differences within each concentration (Figure 1). The C. zeylanicum and S. aromaticum essential oils showed antagonistic effect for mycelial growth already at concentration of $250 \mathrm{ppm}$ with a reduction of $78.70 \%$ and $63.52 \%$, respectively. Lorenzetti et al. (2011) working with the same plants (C. zeylanicum and S. aromaticum) showed effects already observed at $125 \mathrm{ppm}$ with reduction on the mycelial growth of Botrytis cinerea in $41 \%$ and $31 \%$, respectively.

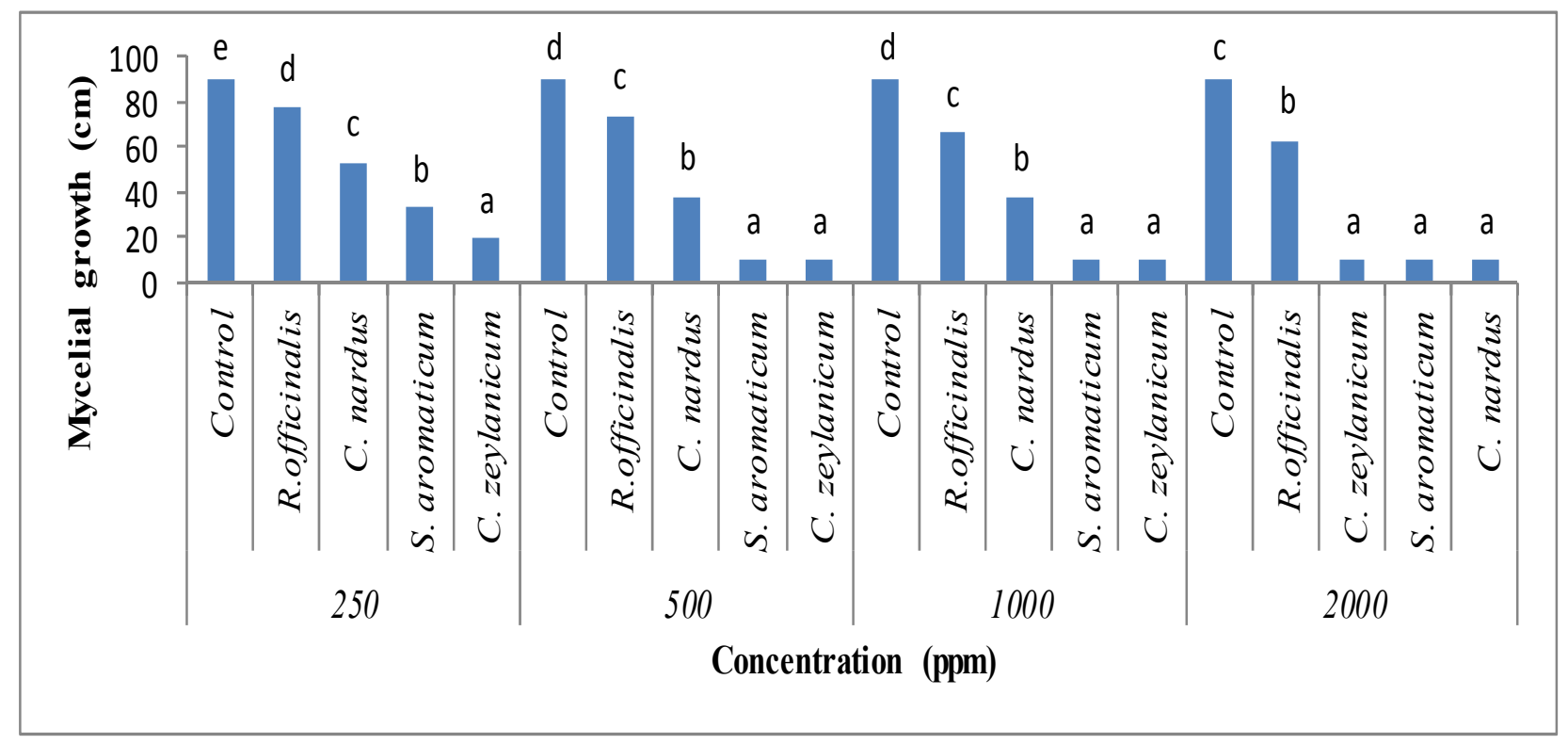

Figure 1. Mycelial growth under influence of the essential oils diluted in the culture medium $* \mathrm{P}=0.05$; Coeficient of Variation $(\mathrm{CV})=5.89$.

The rosemary essential oil does not lend itself to efficient control of fungus under in vitro conditions when compared to other essential oils. However, a weak growth inhibition can be achieved with increasing dose, as shown in the work of Pereira et al. (2006) which report the mycelial growth inhibition of Fusarium sp. in $31.89 \%$ at the concentration of $2000 \mu \mathrm{g} / \mathrm{mL}$. The essential oil of C. nardus obtained intermediate result and also was efficient at high concentrations. Alves et al. (2002) also reported the efficiency of $C$. nardus essential oil in controlling mycelial growth in vitro. The best results considering all concentrations were obtained by the essential oils from S. aromaticum and C. zeylanicum (Figure 2). 


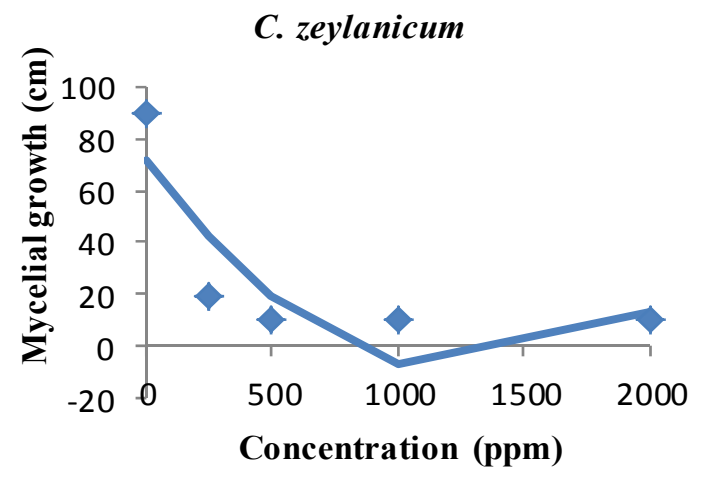

$\mathrm{y}=0.00005^{2}-0.1281 \mathrm{x}+71.23$

$\mathrm{R}^{2}=73.65^{*}$

\section{S. aromaticum}

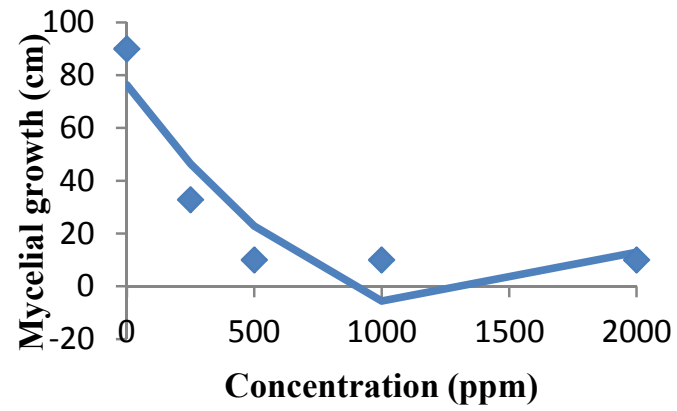

$\mathrm{y}=0.00005^{2}-0.131975 \mathrm{x}+76.28$

$\mathrm{R}^{2}=83.61 *$

Figure 2. Regression analysis for the best essential oils in controlling of mycelial growth

* Significant differences in $\mathrm{F}$ test at 5\% probability.

\subsection{Mycelial Growth under Influence of Plant Extracts Incorporated in the Culture Medium}

The result for the treatments with plant extracts on the mycelial growth showed significant differences within each concentration (Figure 3). The extracts of C. zeylanicum and $S$. aromaticum at 5\% concentration reduced mycelial growth to $40.37 \%$ and $54.44 \%$, respectively. Rozwalka et al. (2008) when working with extracts of S. aromaticum and $R$. officinalis reported the control of Glomerella cingulata and Colletotrichum gloeosporioides, being observed a decrease about $64.71 \%$ and $100 \% ; 100 \%$ and $49.43 \%$, respectively.

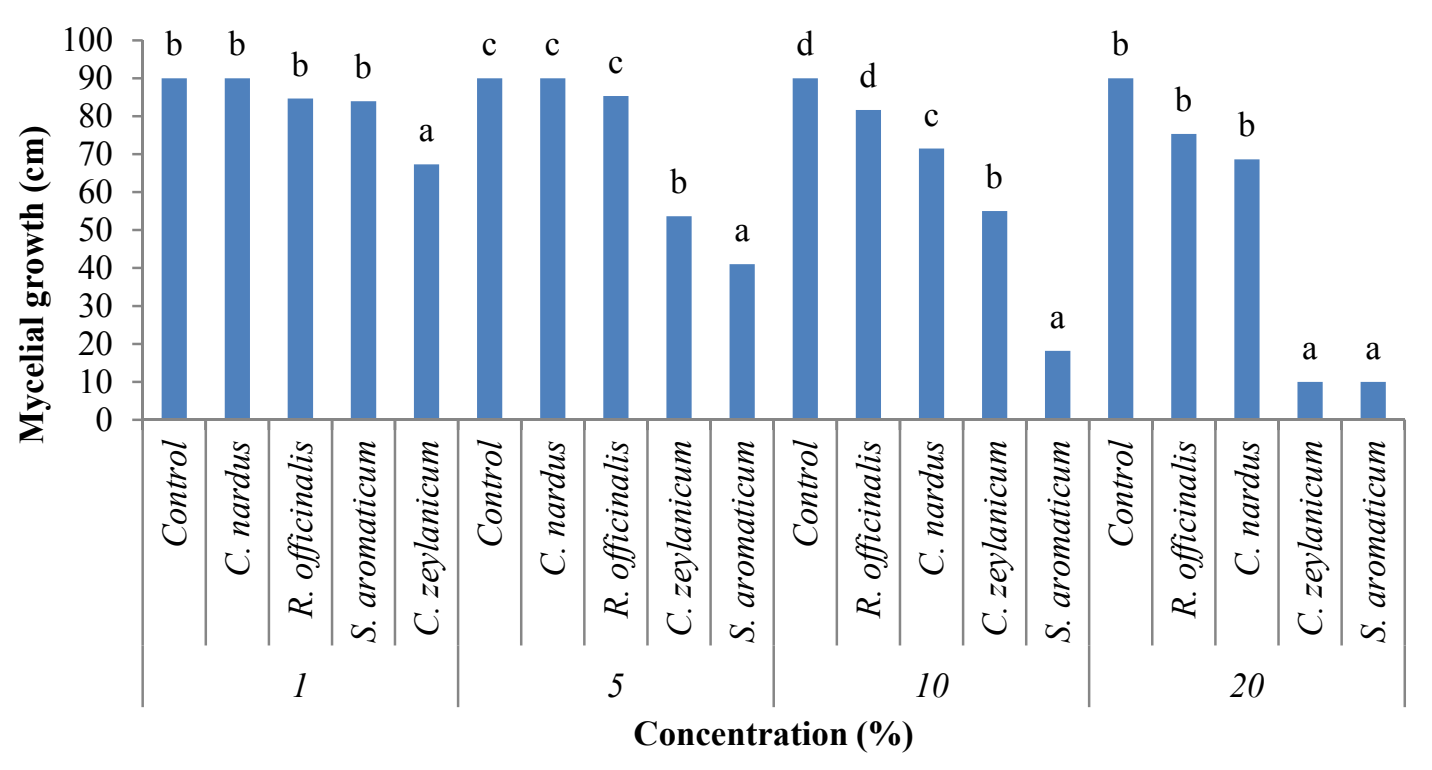

Figure 3. mycelial growth under the influence of plant extracts incorporated in the culture medium $* \mathrm{P}=0.05 ; \mathrm{CV}=5.57$.

The $R$. officinalis extract does not lend itself to efficient control of fungus in vitro conditions, when it compared to other oils, obtaining values statistically equal to the control. Kashima et al. (2009) achieved a reduction at $49.06 \%$ 
on the mycelial growth of Cladosporium fulvum only at high concentrations (40\%). The extract of C. nardus also had no effect on mycelial growth. Moreira et al. (2008) working with ethanol and methanol extracts from $C$. nardus observed that these had no direct fungitoxicity against $C$. lagenarium. The best results considering all concentrations were obtained by plant extracts from S. aromaticum and C. zeylanicum (Figure 4).

S. aromaticum

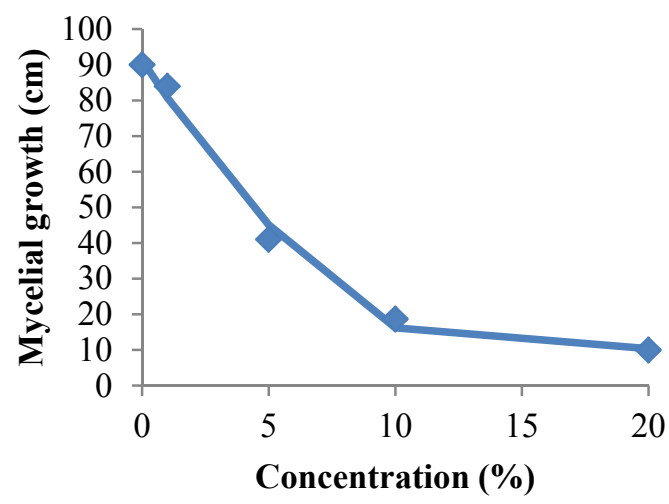

$\mathrm{y}=0.3451^{2}-10.9697 \mathrm{x}+91.30$

$\mathrm{R}^{2}=99.34 *$

\section{C. zeylanicum}

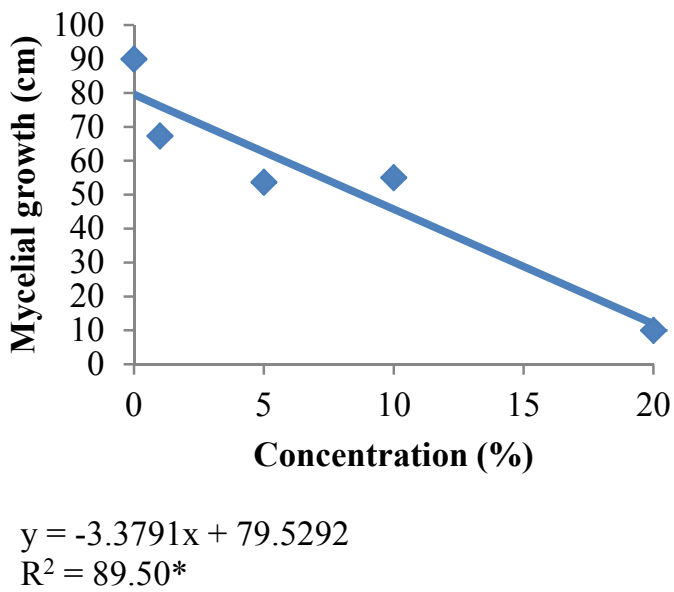

Figure 4. Regression analysis for the best plant extracts to prevent mycelial growth

* Significant differences in $\mathrm{F}$ test at 5\% probability.

\subsection{Mycelial Growth under the Influence of Volatile Essential Oils}

The result for the volatile effect of essential oils on the mycelial growth showed significant differences only at concentrations higher than 1000 ppm (Figure 5).

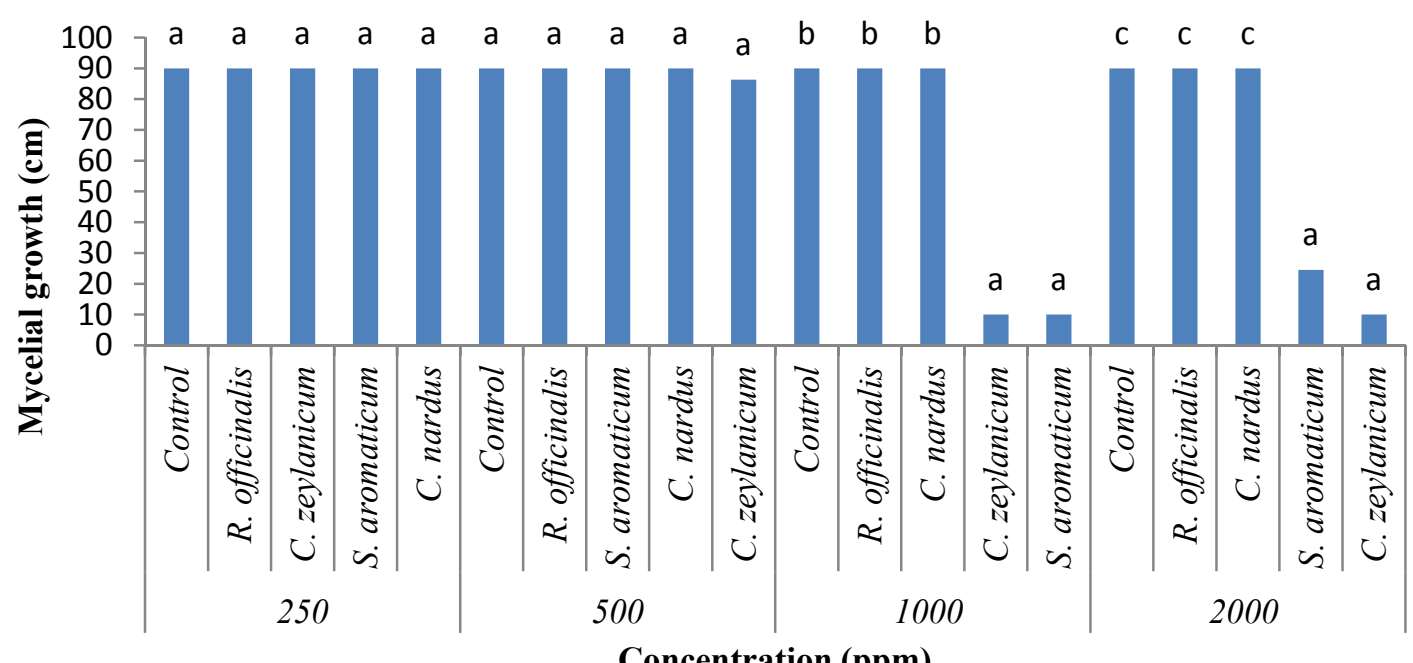

Figure 5. Mycelial growth under influence of volatile essential oils incorporated in the culture medium $* \mathrm{P}=0.05 ; \mathrm{CV}=4.75$. 
The best results considering the concentrations of $1000 \mathrm{ppm}$ and $2000 \mathrm{ppm}$ were obtained by plant extracts from $S$. aromaticum and C. zeylanicum (Figure 6). These volatile essential oils at concentration of $1000 \mathrm{ppm}$ reduced the mycelial growth in $88.89 \%$. The volatile essential oils from $R$. officinalis and C. nardus showed no difference compared to control.

\section{S. aromaticum}

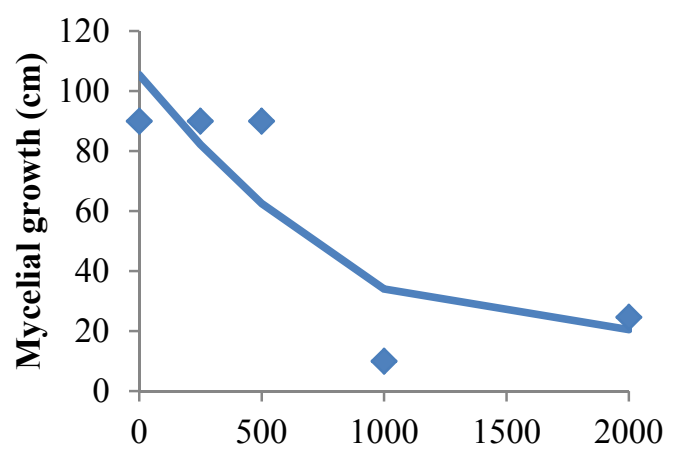

Concentration (ppm)

$\mathrm{y}=0.00003^{2}-0.1003 \mathrm{x}+105.4462$

$\mathrm{R}^{2}=74.38^{*}$

\section{C. zeylanicum}

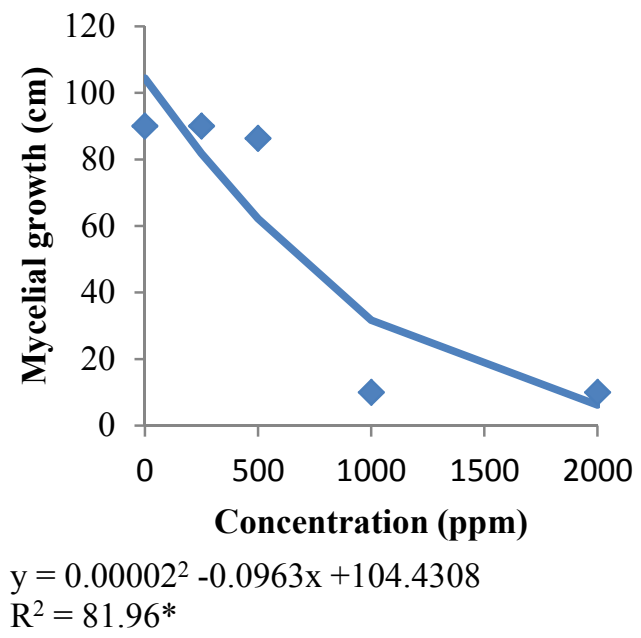

Figure 6. Regression analysis for the best essential oils to prevent mycelial growth

* Significant differences at $\mathrm{F}$ test at $5 \%$ probability.

\subsection{Mycelial Growth under the Influence of Volatile Plant Extracts}

The volatiles from plant extracts did not inhibit mycelial growth in any concentrations compared with the control (Figure 7). Although some plants have antagonistic compounds as shown by the results of its essential oils in previous experiment, maybe the extracts do not have sufficient volatile components or the active form to inhibit mycelial growth may be the answer for this results.

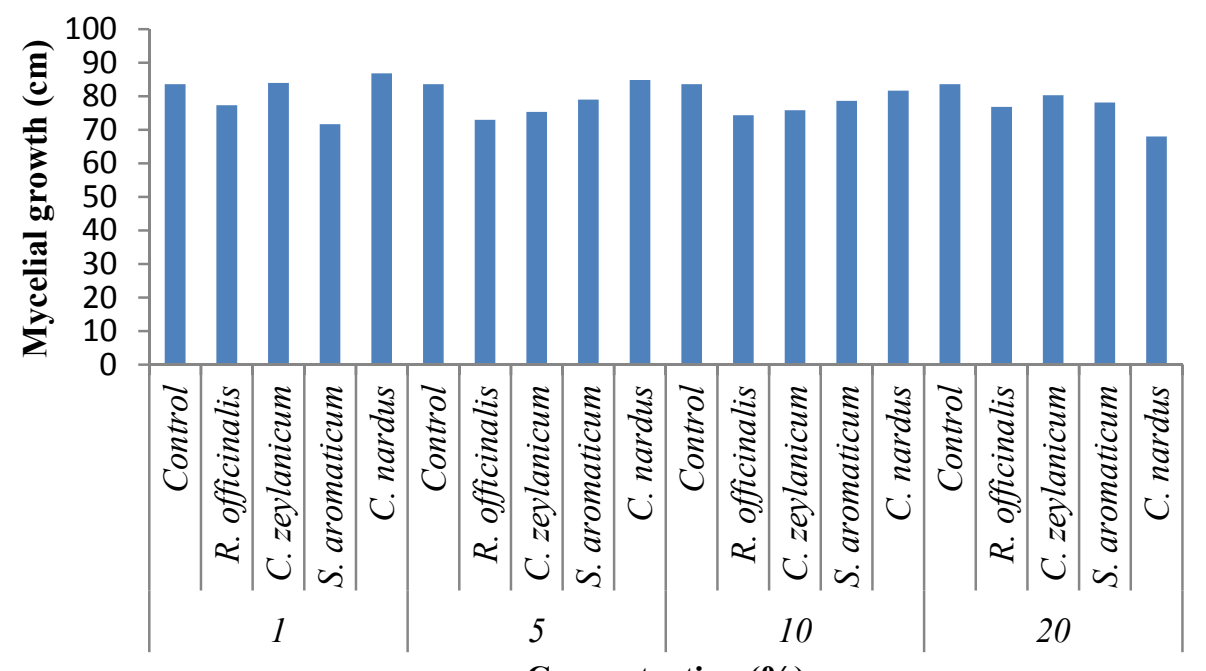

Concentration (\%)

Figure 7. Mycelial growth under influence of volatile plant extracts incorporated in the culture medium 


\subsection{Essential Oils Effect on the Conidial Germination}

The essential oils showed significant difference on the conidial germination at various concentrations (Figure 8), demonstrating the superiority of treatment with S. aromaticum and C. zeylanicum (Figure 9). These essential oils from $S$. aromaticum and C. zeylanicum inhibited germination of conidia in 81.64 and $74.22 \%$, respectively. Lorenzetti et al. (2011) also observed the positive effect of essential oil from C. zeylanicum and S. aromaticum inhibited $100 \%$ on the spore production and germination of $B$. cinerea.

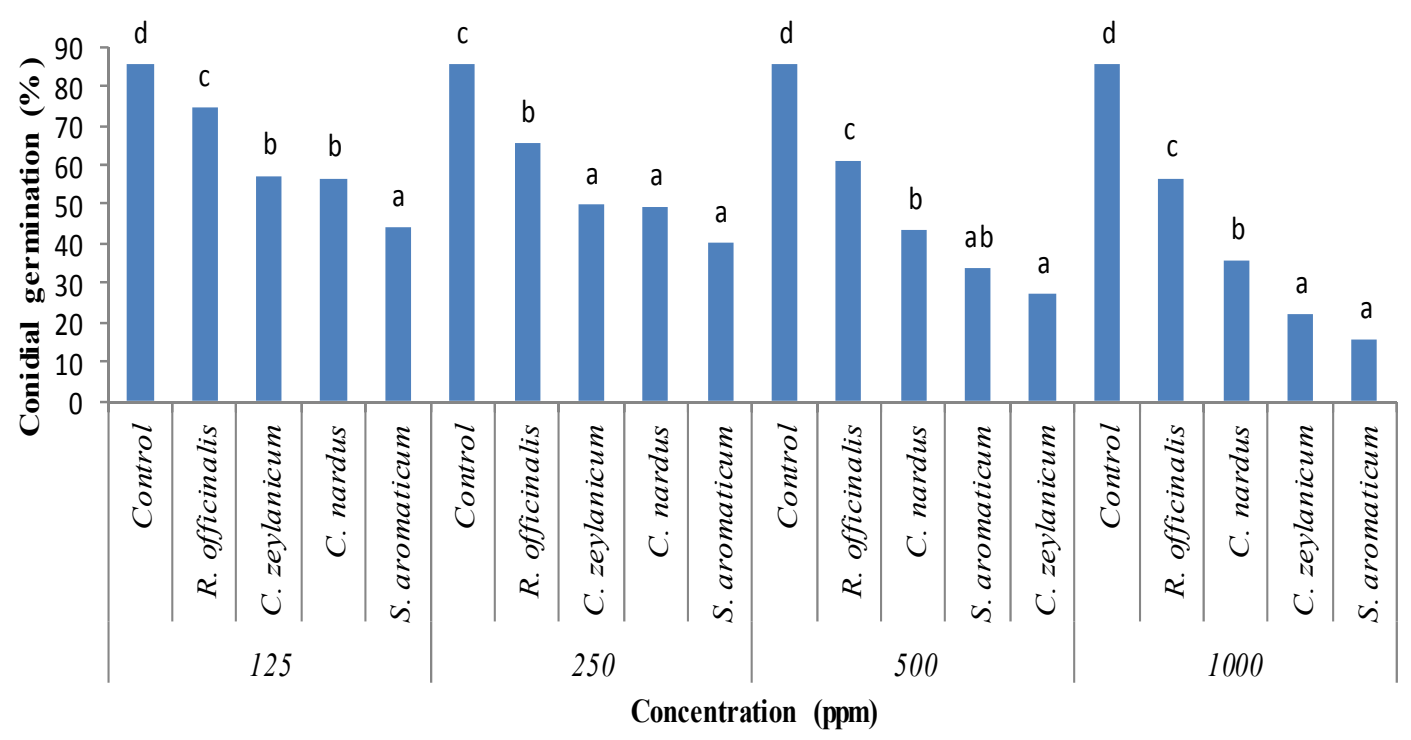

Figure 8. Conidial germination under the effect of essential oils

$* \mathrm{P}=0.05 ; \mathrm{CV}=8.45$.

The essential oil from $R$. officinalis was not effective in inhibiting the conidial germination. The essential oil from C. nardus was intermediate showing better efficiency at a concentration of $1000 \mathrm{ppm}$. Wilson et al. (1997) also reported the antifungal effect of the essential oil from $C$. nardus at a concentration of $6.25 \%$ on the spores of $B$. cinerea.

S. aromaticum

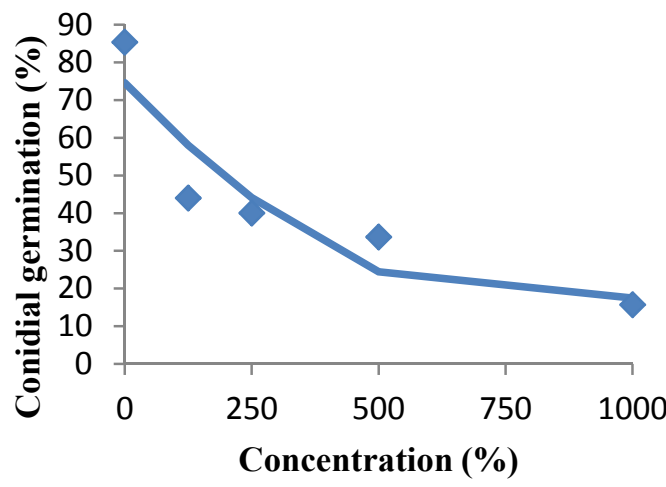

$\mathrm{y}=0.000086^{2}-0.1435 \mathrm{x}+74.5949$

$\mathrm{R}^{2}=84.17$
C. zeylanicum

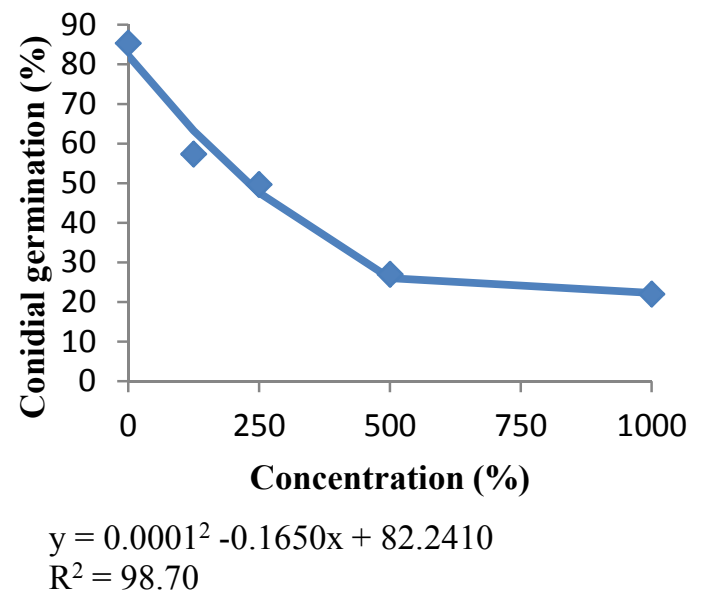

Figure 9. Regression analysis for the best essential oils in controlling of mycelial growth

* Significant differences at $\mathrm{F}$ test on 5\% probability. 


\subsection{Plant Extracts Effect under Conidial Germination}

The plant extracts from S. aromaticum and C. zeylanicum also had higher levels of control at concentration tested (Figure 10, Figure 11). The best control was imposed by the extracts of S. aromaticum and C. zeylanicum having reduced the mycelial growth by 94.93 and $79.69 \%$, respectively.

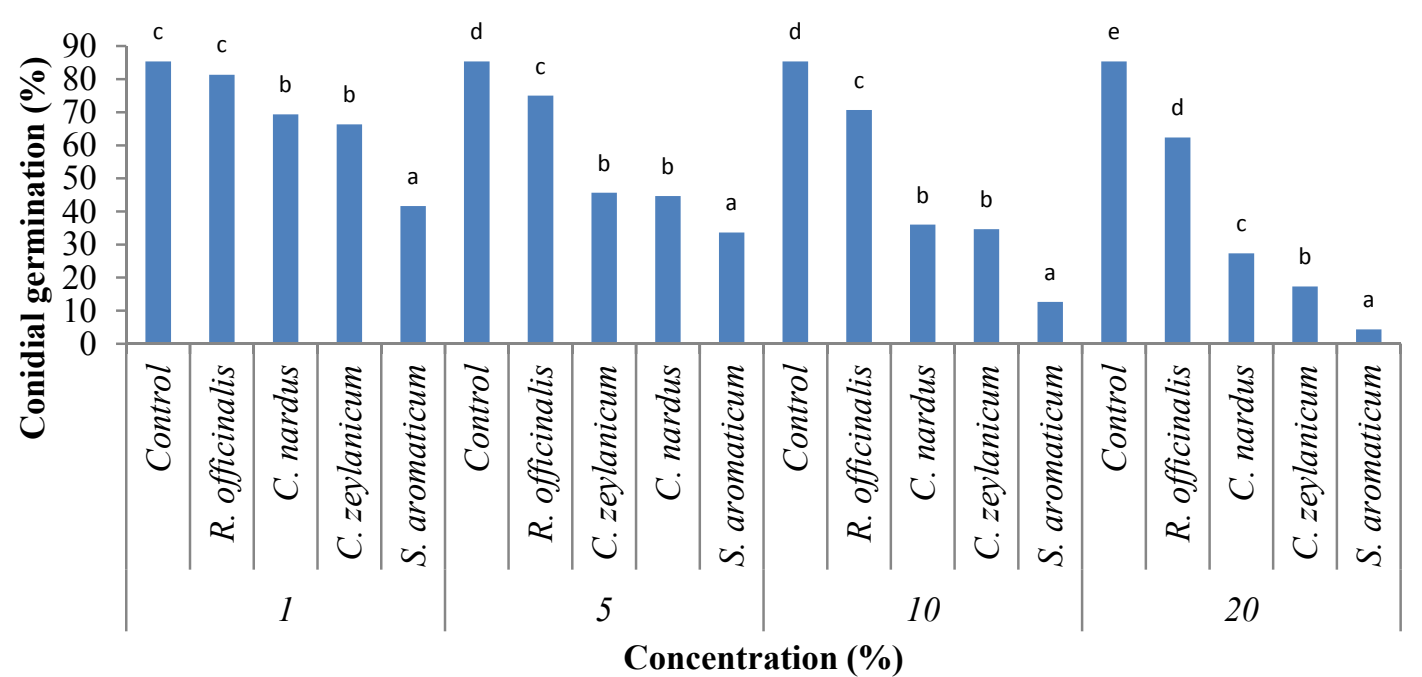

Figure 10. Conidial germination under the effect of plant extracts

$* \mathrm{P}=0.05 ; \mathrm{CV}=6.54$.

Kashima et al. (2008) working with the extract of $R$. officinalis observed that just $59.5 \%$ of the spores from Alternaria solani were germinated. In this study, the extract of $R$. officinalis obtained the lowest results. The extract of $C$. nardus showed control values intermediaries. Franzener et al. (2007) working with the $C$. nardus hidrolact and Alternaria brassicae noticed the promotion on the conidial germination instead of your control.

\section{S. aromaticum}

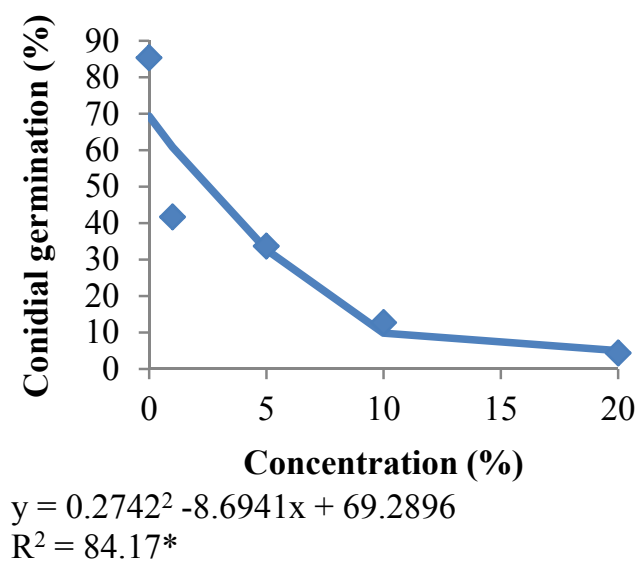

\section{C. zeylanicum}

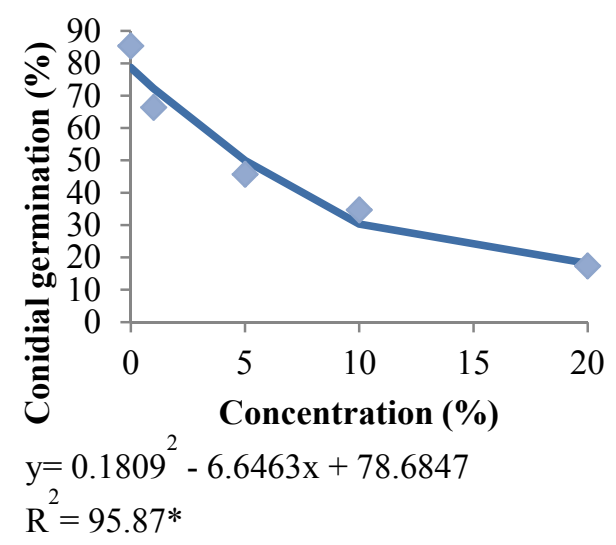

Figure 11. Regression analysis for the best plant extracts on the control of mycelial growth

* Significant differences at $\mathrm{F}$ test on $5 \%$ probability. 


\subsection{Disease Severity Assessment In Vivo}

The results for this test showed that both essential oils and extracts from C. zeylanicum and S. aromaticum achieved the best values in controlling the disease (Figure 12 and 13), obtaining values equal to fungicide treatment. The extracts and essential oils from $R$. officinalis and $C$. nardus were equal to fungicide, a fact explained, because it had no effect on the fungus. This result can represent something new on the treatment of this disease, that up to now there is no effective control. The essential oils, which showed a less severity, could be explored to control this disease. In our conditions, we have not seen any phytotoxic effects caused by plants extracts or essential oils.

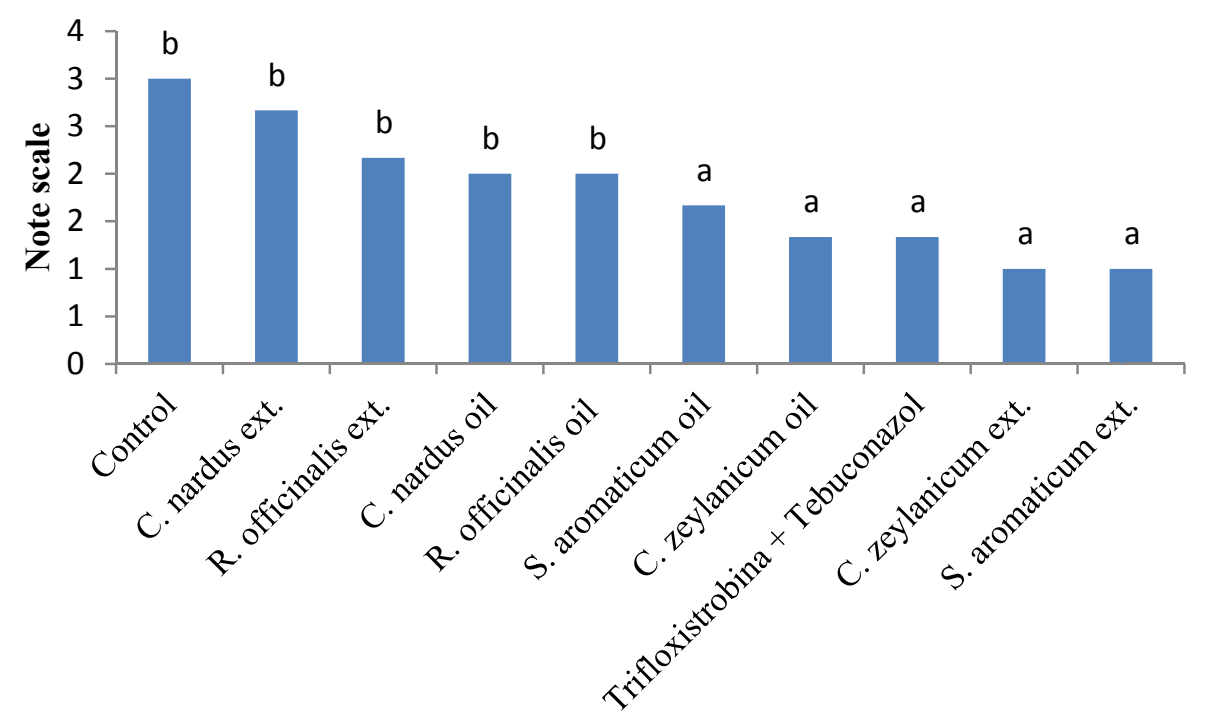

Figure 12. Notes given for the disease severity on the in vivo evaluation

$* \mathrm{P}=0.05 ; \mathrm{CV}=5.57$.

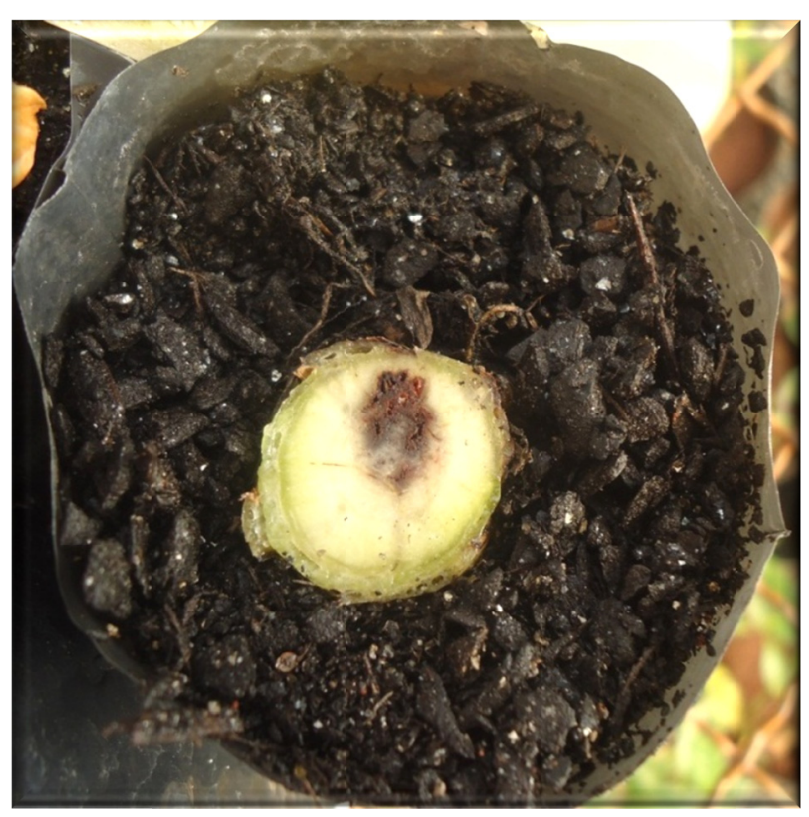

Figure 13. Pseudo-stem infected with F. oxysporum f. sp. cubense showing symptoms of Panama disease 


\section{Conclusion}

The plant extracts and essential oils from $S$. aromaticum and $C$. zeylanicum controlled the $F$. oxysporum f. sp. cubense in all tests performed in these study, showing good control on the mycelial growth using volatiles and also when it was diluted in culture medium, as well as on the conidial germination.

The plant extracts and essential oils of S. aromaticum and C. zeylanicum controlled the disease progress of Panama disease.

\section{Acknowledge}

To Coordenação de Aperfeiçoamento de Pessoal de Nível Superior (CAPES) and Fundação de Amparo à Pesquisa do Estado de Minas Gerais (FAPEMIG), for providing the scholarship.

\section{References}

Alves, E. S. S., Santos, M. P., Ventura, J. A., \& Fernandes, P. M. B. (2002). Eficiência de óleos essenciais no controle in vitro da germinação de conídios e do crescimento micelial de Colletotrichum musae. Fitopatologia Brasileira, 27(spe), 75.

Bajpai, V. K., Rahman, A., \& Kang, S. C. (2007). Chemical composition and anti-fungal properties of the essential oil and crude extracts of Metasequoiaglyp tostroboides Miki ex Hu. Industrial Crops and Products, 26(1), 28-35. http://dx.doi.org/10.1016/j.indcrop.2006.12.012

Bancroft, J. (1876). Report of the board appointed to enquire into the cause of disease affecting livestock and plants. Votes and Proceedings, 3, 1011-1038.

Barbiéri, R. S., Lima, E. P., Silva, S. F., Dias, A. K. C., Cardoso, M. G., \& Terra, V. R. (2006). Síntese e caracterização de um novo composto obtido pela reação entre hidreto de trifenilestanho e ácido $( \pm)$-mandélico e avaliação de seu potencial biocida sobre o fungo Fusarium oxysporum f. sp. cubense. Ciência eAgrotecnologia, 30(3), 467-473. http://dx.doi.org/10.1590/S1413-70542006000300012

Beckman, C. H. (1990). Host responses to the pathogen. In R. C. Ploetz (Ed.), Fusarium Wilt of Banana (pp. 93-105). American Phytopathological Society, St. Paul, APS Press.

Braga filho, J. R., Nascimento, J. L., Naves, R. V., \& Torres, M. C. L., Geraldine, R. M., Souza, E. R. B., \& Barroso, F. V. (2011). Lâminas de irrigação e genótipos na produção e qualidade de frutos de bananeira. Pesquisa Agropecuária Tropical, 41(2), 155-162.

Cakir, A., Kordali, S., Kilic, H. \& Kaya, E. (2005). Antifungal properties of essential oil and crude extracts of Hypericum linarioides Bosse. Biochemical Systematics and Ecology, 33(3), 245-256. http://dx.doi.org/10.1016/j.bse.2004.08.006

Cruz, S. M. C., Rodrigues, A. A. C., Coelho, R. S. B., \& Sardinha, D. H. S. (2011). Ação indutora de produtos abióticos na resistência de tomateiro e efeito sobre o crescimento micelial de Fusarium oxysporum f. sp. Lycopersici. IDESIA, 29(2), 111-118.

Daly, A., \& Walduck, G. (2006). Fusarium wilt of bananas (Panama Disease) (Fusarium oxysporum f. sp. cubense). Department of Primary Industry, Fisheries and Mines, Agnote No: 151: 1-5.

Ferreira, D. F. (2000). Sistema de análises de variância para dados balanceados. Lavras: UFLA, 2000. (SISVAR 4. 1. Computacional pack).

Franzener, G., Martinez-franzener, A. S., Stangarlin, J. R., Czepak, M. P., Schwan-estrada, K. R. F., \& Cruz, M. E. S. (2007). Antibacterial, antifungal and phytoalexins induction activities of hydrolates of medicinal plants. Semina-Ciências Agrárias, 28(1), 29-38.

Guimarães, L. G. L., Cardoso, M. G., Souza, P. E., Andrade, J., \& Vieira, S. S. (2011). Atividades antioxidante e fungitóxica do óleo essencial de capim-limão e do citral. Ciência agronômica, 42(2), 464-472. http://dx.doi.org/10.1590/S1806-66902011000200028

Higgins, J. E. (1904). The Banana in Hawaii. Hawaii Agric. Expt. Stn. Bull., 7.

Itako, A. T., Schwan-Estrada, K. R. F., Stangarlin, J. R., Tolentinojúnior, J. B., \& Cruz, M. E. S. (2009). Controle de Cladosporium fulvum em tomateiro por extratos de plantas medicinais. Arquivos do Instituto Biológico, 76(1), 75-83.

Itako, A. T., Schwan-estrada, K. R. F., Tolentinojúnior, J. B., Stangarlin, J. R., \& Cruz, M. E. S. (2008). Atividade antifúngica e proteção do tomateiro por extratos de plantas medicinais. Tropical Plant Pathology, 33(3), 241-244. http://dx.doi.org/10.1590/S1982-56762008000300011 
Lorenzetti, E. R., Monteiro, F. P., Souza, P. E., Souza, R. J., Scalice, H. K., Diogo J. R., ... Pires, M. S. O. (2011). Bioatividade de óleos essenciais no controle de Botrytis cinereaisolado de morangueiro. Revista Brasileira de Plantas Medicinais, 13(spe), 619-627. http://dx.doi.org/10.1590/S1516-05722011000500019

Moreira, C. G. A., Schwan-Estrada, K. R. F., Bonaldo, S. M., Stangarlin, J. R., \& Cruz, M. E. S. (2008). Caracterização parcial de frações obtidas de extratos de Cymbopogon nardus com atividade elicitora de fitoalexinas em sorgo e soja e efeito sobre Colletotrichum lagenarium. Summa Phytopathologica, 34(4), 332-337. http://dx.doi.org/10.1590/S0100-54052008000400006

Oliveira, O. R., Terao, D., Carvalho, A. C. P. P., Innecco, R., \& Albuquerque, C. C. (2008). Efeito de óleos essenciais de plantas do gênero Lippia sobre fungos contaminantes encontrados na micropropagação de plantas. Ciência Agronômica, 39(1), 94-100.

Pereira, J. C. R., \& Gasparoto, L. (2006). Contribuição para o reconhecimento das sigatoka negra e amarela e doenças vasculares (Musa spp.). EMBRAPA, 2006.

Pereira, J. C. R., Pereira, J. R., Castro, M. E. A., \& Gasparotto, L. (2005). Ocorrência do mal-do-panamá em bananeira do subgrupo Figo, em Piau, Minas Gerais. Fitopatologia Brasileira, 30(5), 574. http://dx.doi.org/10.1590/S0100-41582005000500022

Pereira, M. C., Vilela, G. R., Costa, L. M. A. S., Silva, R. F., Fernandes, A. F., Fonseca, E. W. N., \& Piccoli, R. H. (2006). Inhibition fungi growth through of utilization essential oils of spice. Ciência e Agrotecnologia, 30(4), 731-738.

Ploetz, R. C. (2000). Panama disease: A Classic and Destructive Disease of Banana. Plant Health Progress, 1-7.

Ploetz, R. C., \& Pegg, K. G. (1997). Fusarium wilt of banana and Wallace's line: Was the disease originally restricted to his Indo-Malayan region? Australasian Plant Pathology, 26(4), 239-249. http://dx.doi.org/10.1071/AP97039

Rozwalka, L. C., Lima, M. L. R. Z. C., Mio, L. L. M., \& Nakashima, T. (2008). Extracts, decoctions and essential oils of medicinal and aromatic plants in the inhibition of Colletotrichum gloeosporioides and Glomerella cingulata isolates from guava fruits. Ciência Rural, 38(2), 301-307.

Stover, R. H. (1962). Fusarial Wilt (Panama Disease) of Bananas and Other Musa Species. CMI, Kew, Surrey, UK.

Wilson, C. L., Solar, J. M., El ghaouth, A., \& Wisniewski, M. E. (1997). Rapid evaluation of plant extracts and essential oils for antifungal activity against Botrytis cinerea. Plant Disease, 81(2), 204-210. http://dx.doi.org/10.1094/PDIS.1997.81.2.204 